\title{
Aspects of varicella-zoster infection in children
}

\author{
Consuela Marcaş*, Ana Maria lancu, Ilie Maria Margareta \\ From The 9th Edition of the Scientific Days of the National Institute for Infectious Diseases Prof Dr Matei \\ Bals \\ Bucharest, Romania. 23-25 October 2013
}

\section{Background}

Herpes zoster is an infectious and contagious disease caused by the reactivation of latent varicella-zoster virus. Shingles occurs sporadically and usually in adults and the elderly (over $90 \%$ of the cases occur after the age of 20 years). It occurs rarely in children (5\%).

\section{Methods}

We studied the cases of herpes zoster which were admitted in the hospital in the last 12 months (June 2012July 2013) in the Pediatric Department.

\section{Results}

Seven children and infants were admitted with a of diagnosis herpes zoster based on clinical judgment. Their ages were between 4 months and 5 years, three of them being infants. None of the children had prior exposure to varicella-zoster virus during gestation or early infancy.

One case presented ocular involvement, 6 patients had thoracic form. One of the infants presented a spread of infection to more dermatomes. Two patients presented complications (cardiac and digestive). None of the children were not vaccinated.

\section{Conclusion}

Compared to previous years, we noticed a decreasing age of children and infants with this condition. All children and infants were without medical history of chickenpox. None of the mothers had presented chickenpox in the second or third trimester of pregnancy.
Published: 16 December 2013

doi:10.1186/1471-2334-13-S1-P93

Cite this article as: Marcas et al:: Aspects of varicella-zoster infection in children. BMC Infectious Diseases 2013 13(Suppl 1):P93.

\footnotetext{
* Correspondence: consuela82000@yahoo.com

Clinical Hospital of Infectious Diseases, Constanța, Romania
}

Submit your next manuscript to BioMed Central and take full advantage of:

- Convenient online submission

- Thorough peer review

- No space constraints or color figure charges

- Immediate publication on acceptance

- Inclusion in PubMed, CAS, Scopus and Google Scholar

- Research which is freely available for redistribution 